\title{
In vitro study on thiabendazole action on viability of Ascaris lumbricoides (Lineu, 1758) eggs
}

\author{
Estudo in vitro da ação do tiabendazol sobre a viabilidade de \\ ovos de Ascaris lumbricoides (Lineu, 1758) \\ Cristiano Lara Massara', Rafaela Salgado Ferreira', \\ Henrique Leonardo Guerra ${ }^{2}$ and Omar dos Santos Carvalho'
}

\begin{abstract}
The in vitro activity of thiabendazole on Ascaris lumbricoides eggs, which were recovered from uteri of worm excreted after chemotherapeutic treatment, was studied. Four concentrations of the drug were used: 1 $-2.5-5$ - and 10 ppm during 24, 48 and 72 hours of exposure. Subsequently, the eggs were centrifuged, washed three times and $\mathrm{H}_{2} \mathrm{SO}, 0.1 \mathrm{~N}$ was added. The eggs were maintained in an incubator for 20 days at $28^{\circ}$ C. Finally, the percentage of embryonated eggs was determined under a lightmicroscope at a $100 X$ magnification. After 48 and 72 hours of thiabendazole exposure, at a concentration of 10ppm, the drug showed complete inhibition of egg embryonation.
\end{abstract}

Key-words: Ascaris lumbricoides. Thiabendazole. Ovicide.

Resumo Foi estudada, in vitro, a ação do tiabendazol, contra ovos de Ascaris lumbricoides, retirados de úteros de vermes eliminados após tratamento. Foram utilizadas quatro concentrações da droga: 1-2,5 - $5 e$ 10 ppm em três diferentes períodos de tempo: 24, 48 e 72 horas. Decorridos estes tempos a suspensão com os ovos foi centrifugada, lavada por três vezes com água destilada, adicionada de solução de $\mathrm{H}_{2} \mathrm{SO}_{4}, 0,1 \mathrm{Ne}$ mantida em estufa a $28^{\circ} \mathrm{C}$ por 20 dias. Em seguida, os ovos foram levados ao microscópio óptico, no aumento de 100X, para observação do percentual de embrionamento. Na concentração de 10ppm, nos tempos de $48 \mathrm{e}$ 72 horas de exposição à droga, verificou-se completa inibição do embrionamento dos ovos.

Palavras-chaves: Ascaris lumbricoides. Tiabendazol. Ovicida.

Parasitic diseases are an important public health problem in most developing countries. Latin American and African populations are found to be parasitized by at least one helminth species ${ }^{18}$.

It is estimated that there are 2 billion people at risk of helminth infections. Of these, 250 million are infected by Ascaris lumbriocides, 46 million by Trichuris trichiura, 151 million by hookworms and 56 million by Strongyloides stercoralis ${ }^{171517}$.

Gastrointestinal parasitic diseases are highly prevalent in Brazil as they are closely associated with poor living conditions, such as inadequate housing, lack of food and basic sanitation as well as low educational level, leading to failure to perform basic hygiene.

Several research groups 3491011121620 have been developing, testing and using drugs which act both on individual treatment and interrupting helminthes life cycle.
Current anthelmintics are only used to temporarily decrease the parasitic prevalence indices. Since the drug effects are not ovicidal, the eggs are regularly excreted on the ground through the feces, leading to new infections ${ }^{1619}$.

By using thiabendazole in pigs experimentally infected with Ascaris suun, Egerton ${ }^{3} 4$ observed morphological changes in the eggs and inhibition of embryonation.

Kutsumi et $a^{12}$ added thiabendazole to the nightsoil and verified a decrease in human hookworm, $A$. lumbricoides and T. trichiura transmission in three areas, compared with non-treated areas.

Goulart et a/ ${ }^{6}$ treated egg cultures of Ascaris lumbricoides, T. trichiura and Ancylostoma caninum with thiabendazole, using 1,10 and $100 \mathrm{mg}$ doses and demonstrated the ovicidal inefficiency of this anthelmintic for the first two parasite species.

\footnotetext{
1. Laboratório de Helmintoses Intestinais do Centro de Pesquisas René Rachou da Fundação Oswaldo Cruz. Belo Horizonte, MG, Brasil 2. Laboratório de Epidemiologia e Antropologia Médica do Centro de Pesquisas René Rachou da Fundação Oswaldo Cruz. Belo Horizonte, MG

Address to: Dr. Cristiano Lara Massara. Centro de Pesquisas René Rachou/FIOCRUZ. Caixa Postal 143, 30190-970 Belo Horizonte, MG.

Telefax 55 313295-3115

e-mail:massara@cpqrr.fiocruz.br

Recebido para publicação em 11/7/2000
} 
Massara et a ${ }^{14}$ studied in vivo six common drugs for the treatment of several helminth infections. Among these drugs, only thiabendazole proved ovicidal on A. lumbricoides eggs 48 hours after treatment. After chemotherapy of humans, this drug was also effective on the eggs found in the uteri of eliminated worms ${ }^{2}$.

Thiabendazole, a benzimidazole derivative, has been known for over 30 years and is the drug of choice for strongyloidiasis treatment. The adverse reactions are slight: nausea, vomit, giddiness and sleepiness ${ }^{19}$.

From this prospect the authors have identified in vitro the minimum thiabendazole dose with ovicidal activity on $A$. lumbricoides eggs.

This approach can provide new possibilities in the control of the gastrointestinal helminth diseases, by preventing environmental contamination with viable parasite eggs.

\section{MATERIAL AND METHODS}

Patients and treatment. Stool samples were collected from elementary school students (7 to 14 years old) attending the Municipal School of Sabará, municipality of Belo Horizonte. The parasitological diagnosis for the feces was performed using the Kato-Katz method ${ }^{8}$. Two slides per sample were examined. Egg-positive patients with viable A. lumbricoides eggs were treated with levamisole (non ovicidal drug ${ }^{14}$ ) at a single dose of $150 \mathrm{mg}$, independent of the body weight. Students with other helminth diseases or with infertile $A$. lumbricoides eggs were treated with mebendazole, $100 \mathrm{mg}$ base salt, twice a day, for three consecutive days. The treatment was performed after written consent from the parents or legal guardian.

Worm collection and recovery of eggs. Whole feces from each child with ascariasis, eliminated 24, 48 and 72 hours after treatment were collected in plastic flasks. Eliminated females worms were placed on cork plates, dissected and their uteri were removed, and fragmented for the recovery of the eggs.

Egg culture. About twenty thousand eggs/female were transferred into Falcon tubes (volume $15 \mathrm{ml}$ ) containing $5 \mathrm{ml}$ of thiabendazole/DMSO (dimethyl sulfoxide) and were diluted with distilled water at concentrations of 1, 2.5, 5 and 10ppm/tube.

For each female worm, 13 tubes were prepared (12 test tubes and one control tube, with only $\mathrm{H}_{2} \mathrm{SO}_{4} 0.1 \mathrm{~N}$ ): a set of 4 tubes each was exposed to the drug (at concentrations of 1, 2.5, 5.0 and 10ppm thiabendazole) for 24, 48 and 72 hours, respectively. This experimental procedure was performed in duplicate. The eggs were incubated with the drug for 24, 48 and 72 hours in a mechanical shaker at $28^{\circ} \mathrm{C}$. Subsequently, the tubes were centrifuged, washed three times with distilled water and then $5 \mathrm{ml}$ of a $\mathrm{H}_{2} \mathrm{SO}_{4}$ solution $0.1 \mathrm{~N}^{5}$ were added. After washing, eggs were incubated again for 20 days at $20^{\circ} \mathrm{C}$ in a mechanical shaker. Following this step, one sample from each tube was placed between two slides and examined under the microscope in order to determine the percentage of embryonated eggs. Test tubes with viable eggs from a total of 36 worms were evaluated.

To verify a possible interference with the DMSO, a parallel experiment was performed: two concentrations of the diluent ( 1 and 10ppm) were tested in the presence of 20,000 eggs and processed as described above. These eggs were recovered from a pool of females.

Statistics. Data analysis was performed through linear multiple regression. The dependent variant was the embryonation percentage of the eggs in culture, and the independent ones were the concentration of the drug (1.0, $2.5,5.0$ and 10.0ppm), drug exposure time (24, 48 and 72 hours) and the origin of the eggs, i.e. A. lumbricoides females from which the eggs were recovered.

\section{RESULTS}

The mean and standard deviation of the percentage of embryonation, according to the exposure time and concentration of the drug, are show in Table 1.

Twenty-four hours after drug exposure the mean values of embryonated eggs were $10.1 \%(10 \mathrm{ppm})$ and $61.4 \%(1 \mathrm{ppm})$. After 48 hours, the percentage of embryonated eggs decreased to $0 \%(10 \mathrm{ppm})$ and to $49.7 \%(1 \mathrm{ppm})$. The mean percentage of embryonated eggs in the control tubes was $65.6 \%$.

Dilutions of the drug at $1 \mathrm{ppm}$ and $2.5 \mathrm{ppm}$ did not interfere with the $A$. lumbricoides egg embryonation. At the concentration of $5 \mathrm{ppm}$, the rate of embryonated eggs rate varied from $0 \%$ to $31 \%$ after a 72 -hour $(x=3.4$; sd \pm 9.4$)$ exposure to the drug. At the concentration of $10 \mathrm{ppm}$, and after a 24-hour exposure, an embryonation rate from $0 \%$ to $72 \%(x=10.1$; sd \pm 19.0$)$ was observed. When the same concentration of the drug was applied for 48 or 72 hours, no embryonated eggs were detected.

Regarding the control experiment with DMSO no inhibition of the egg development was observed and the embryonation rate ranged between from $71 \%$ and $77 \%$. The embryonation rates with $\mathrm{H}_{2} \mathrm{SO}_{4}(0.1 \mathrm{~N})$ varied from $48 \%$ to $98 \%$.

Data analysis showed that there was a statistically significant relationship between the embryonation rate of the eggs and the drug concentration $(b=-5.29, p<0.0001)$ and also to the exposure time of the eggs to the drug $(b=-0.41, p<0.0001)$. Statistically significant differences were also observed when the source of the eggs (variation between the 36 worms) was compared $(b=-0.34$, $p<0.0001)$. The final model, using these three independent variances, was statistically significant $(p<0.0001)$ with $r^{2}=58.54 \%$. 
Table 1 - Percentage of embryonation (mean and standard deviation) from A. lumbricoides egg incubation according to time exposure and thiabendazole concentration.

\begin{tabular}{lrcc}
\hline $\begin{array}{c}\text { Exposure time } \\
(\mathrm{h})\end{array}$ & $\begin{array}{c}\text { Concentration } \\
\text { ppm }\end{array}$ & $\begin{array}{c}\text { Mean embryonation } \\
\%\end{array}$ & $\begin{array}{c}\text { Standard deviation } \\
\%\end{array}$ \\
\hline 24 & 1.0 & 61.4 & 15.3 \\
& 2.5 & 55.7 & 20.0 \\
& 5.0 & 45.4 & 22.2 \\
& 10.0 & 10.1 & 19.0 \\
\hline 48 & 1.0 & 54.1 & 19.2 \\
& 2.5 & 41.6 & 22.8 \\
& 5.0 & 12.8 & 18.9 \\
& 10.0 & 0.0 & 0.0 \\
\hline 72 & 1.0 & 49.7 & 23.6 \\
& 2.5 & 23.8 & 21.2 \\
& 5.0 & 3.4 & 9.4 \\
& 10.0 & 0.0 & 0.0 \\
\hline Control & - & 65.6 & 16.3 \\
\hline
\end{tabular}

Note: Each experiment was performed in duplicate

\section{DISCUSSION}

Treatment, even under correct dosage, promotes a transitory cure, once the epidemiological conditions persist and reinfection occurs. The available drugs are not ovicidal, but promote the elimination of worms from infected individuals and by this mode of action they increase contamination of the environment.

Pawloski ${ }^{17}$ observed that the distribution of ascariasis mirrors the socio-economical development in areas where weather conditions allow the parasite development. Such conditions can prevail in both rural and urban areas.

Control programs in poorer regios concentrate mainly on individual treatment. The use of anthelminthics focus only on the elimination of the worms and a temporary decrease in the prevalence rates ${ }^{14}$. Despite the effectiveness of ascariasis treatment, it can also result in a significant soil contamination since a high number of eggs are eliminated in the feces, enabling the presence of highly infectious microfoci ${ }^{14}$.

Nevertheless, one should also consider that individual treatment is efficient using drugs without ovicidal activity, since they relieve or prevent the patients from the most serious symptoms of the parasitic infection such as abdominal pain, diarrhea, intestinal obstruction (very common among children), and the latter can lead to death. The currently used anthelmintic drugs do not interrupt the life cycle of the parasite and in a short time the prevalence reaches the value before treatment. This suggests the necessity to obtain more efficient drugs or drug combinations which can promote the elimination of the worms from the patients, and that also have ovicidal activity.

The results from the statistical analysis showed a dose-response effect, which supports the hypothesis that the observed results are due to the specific treatment performed. On the other hand, the differences found for the egg source suggest that the biological variation among worms and egg viability influences the results. However, doses of 10 or $5 p p m$ of thiabendazole were sufficient to overcome the effects of this variation.

Although the present results were obtained under different experimental conditions, the findings regarding thiabendazole treatment are in accordance with those obtained by other workers ${ }^{34913}$. However, Goulart et $a^{\beta}$ did not observe any inhibitory effect on embryonation of $A$. lumbricoides and $T$. trichiura eggs.

Massara et a/14 studied six drugs in vivo in routine use (thiabendazole, levamisole, mebendazole, cambendazole, pyrantel pamoate and praziquantel) to treat several intestinal helminth. Thiabendazole proved to be inefficient for the complete elimination of adult worms, but it was the only drug able to inhibit completely the viability of $A$. lumbricoides eggs 48 hours post-treatment.

Carvalho et $a l^{2}$ reported that after the use of thiabendazole in vivo, the eggs recovered from the A. lumbricoides worm uteri were not embryonated, supporting the ovicidal activity of the drug.

In the present study, we were able to demonstrate in vitro that thiabendazole, in the concentration of $10 \mathrm{ppm}$, after a 48 hour-exposure, inhibited completely the embryonation of A. lumbricoides eggs. These results can provide new and more efficient prospects for the treatment of ascariasis by preventing the environmental contamination with viable parasite eggs. 


\section{ACKNOWLEDGEMENT}

\section{To José Geraldo Amorim da Silva for technical assistance.}

\section{REFERENCES}

1. Anderson RM, May RM. Population dynamics of human helmintic infections: control by chemotherapy. Nature 297:557-563, 1982.

2. Carvalho OS, Guerra HL, Massara CL. Development of Ascaris lumbricoides eggs from females eliminated after chemotherapy in man. Memórias do Instituto Oswaldo Cruz 87:49-51, 1992.

3. Egerton JR. The effect of thiabendazole upon Ascaris and Stephanurus infections. Journal of Parasitology 47:37, 1961.

4. Egerton JR. The ovicidal and larvicidal effect of thiabendazole on various helminth species. Texas Reports Biology and Medicine 27 (supl II):561-580, 1969.

5. Fairbairn D. The in vitro hatching of Ascaris lumbricoides eggs. Canadian Journal of Zoology 39:153-62, 1961.

6. Goulart EG, Arruda ME, Jourdan MC. Quimioterápicos antihelmínticos (investigação das ações ovi e larvicida na evolução de Nematódeos enteroparasitas). Revista Brasileira de Medicina 31:791-794, 1974

7. Grove DI. Strongyloidiasis: a major roundworm infection in man. Taylor \& Francis, London - New York - Philadelphia, 1989.

8. Katz N, Chaves A, Pellegrino J. A simple device for quantitative stool thick-smear technique schistosomiasis mansoni. Revista do Instituto de Medicina Tropical de São Paulo 14:397-400, 1972.

9. Kutsumi H. Epidemiological study on the preventive effect of thiabendazole as an ovicide against human hookworm, Trichuris and Ascaris infections. Japansese Journal of Medicine Science and Biology 22:51-64, 1969.

10. Kutsumi H, Hara T, Yamamoto K. Fields trials of thiabendazole as an ovicide in the control of helminth infections. I. Epidemiological analysis of the effectiveness in the control of hookworm infections. Japananese Journal of Parasitology 15:399-411, 1966a.

11. Kutsumi H, Hara T, Yamamoto K. Field trials of thiabendazole as an ovicide in the control of helminth infections. II. Epidemiological analysis of the effectiveness in the control of whipworm infection. Japanese Journal of Parasitology 15:516-527, 1966b.

12. Kutsumi $H$, Komiya $Y$. Effect of thiabendazole as an ovicide on helminth eggs in nightsoli. Japanese Journal of Medical Science and Biology 18:203-224, 1965.

13. Kutsumi H, Hara T, Yamamoto K. Field trials of thiabendazole as an ovicide in the control of helminth infection. III Epidemiological analysis of the effectiveness in the control of Ascaris infection. Japanese Journal of Parasitology 16:15-27, 1967.

14. Massara CL, Costa HMA, Souza DWC, Carvalho OS. Viability of Ascaris lumbricoides eggs eliminated after anti-helmintic therapy. Memórias do Instituto Oswaldo Cruz 86:233-237, 1991.

15. Montresor A, Crompton DWT, Hall A, Bundy DAP, Savioli L. Lineamentos para la evaluacíon de la geohlemintiasis y la esquistossomiasis a nivel de la comunidad. Guía para el manejo de los programas de control, Washington, DC: OPSc. 38p - (Série HCT/AIEPI 16. E), 1998

16. Moreira C, Souza DWC. Estudo da ação de drogas ascaricidas sobre a embriogênese de ovos retirados de fêmeas expelidas após tratamento humano. In: Resumos do IX Congresso da Sociedade Brasileira de Medicina Tropical, Fortaleza, 1973.

17. Pawlowski ZS. Ascariasis. In: Warren Kennedh S, Mahmoud AF (eds) Tropical and Geographical Medicine. 2nd Edition. McGrawHill, New York, p. 369-378, 1990.

18. Rey L. Parasitologia. Editora Guanabara Koogan S.A. Rio de Janeiro, 1991.

19. Souza DWC, Souza MSL, Carvalho OS. Parasitoses Intestinais. In: Marra UD (ed) Medicina Ambulatorial. Guanabara Koogan, Rio de Janeiro, Cap. 46, p. 248-254, 1985

20. Vanhaelen-Lindhout E, Smit AM. Abnormally shaped eggs of Trichuris trichiura after thiabendazole treatment. Tropical and Geographical Medicine 23: 381-384, 1971. 